\title{
Diagnosing the effect of green supply chain management on firm performance: An experiment study among Jordan industrial estates companies
}

\author{
Dmaithan Abdelkarim Almajali ${ }^{{ }^{*}}$
}

${ }^{a}$ Department of Management Information system, Applied science private university, Jordan

\begin{tabular}{l}
\hline C H R O N I C L E \\
\hline Article history: \\
Received March 9, 2021 \\
Received in revised format May 6, \\
2021 \\
Accepted June 172021 \\
Available online \\
July 25 2021 \\
\hline Keywords: \\
Green supply chain management \\
Green Innovation \\
Firm performance \\
Trust
\end{tabular}

\section{A B S T R A C T}

In this study, the way green supply chain management affects green innovation and firm performance was scrutinized. The effect of trust on firm performance was also investigated. A conceptual model was proposed in this study, and it was empirically tested with a survey of 120 Jordanian managers. Green innovation and trust had a significant impact on firm performance, according to the study's findings. On green innovation, green supply chain management was shown to impart a significant impact. However, green supply chain management has little to do with green innovation. Furthermore, green innovation was found to contribute to both green supply chain management and firm performance. Notably, the present study may be skewed and selective because Jordan Industrial Estates has a good environmental rating. Furthermore, as the study was limited to Jordan, one of the major drawbacks is that the findings cannot be generalized.

(C) 2021 Growing Science Ltd. All rights reserved.

\section{Introduction}

Environmental issues arise in tandem with the growth of a company's performance, and this has presented the business domain with a challenge. Despite forces from the government, commercial competition, society, and investors, firms should give strict concentration to the environment in their supply chain and business development, as this could benefit a firm's performance (Almajali et al., 2015a). As a result, green operations, green innovation, in addition to green supply chain management have been regarded as tools with the capability in humanizing company performance. Notably, Green innovation has the ability to assist businesses in reducing the depressing environmental impacts while simultaneously increasing unrestricted confidence, cost effectiveness, efficiency, and market share (Agustia et al., 2019). However, green innovation adoption is a challenging step considering that such adoption entails novel aspects such as green procedure executive, environmental renewal, and green products for consumption, as well as a shift in organizational structure and employee performance from the traditional work paradigm (Ge et al., 2018). Green innovation is achievable if the company considers the environmental impact, such as the unpredictable nature of the climate and the scarcity of natural resources. As a result, the organization must make innovative improvements to its business operations while simultaneously considering the impact on the environment (Almajali et al., 2016b). Green innovation can help a company's performance improve (Ma et al., 2018). This is since improved firm performance might result in a competitive advantage. However, firm performance is not majorly affected by green supply chain management since only a few firm owners or managers have applied it in their organizations (Khan \& Qianli, 2017). Abu Seman et al. (2019) accordingly reported a considerable impact of green supply chain management on green innovation, especially among companies with increasing green innovation upon their implementation of green supply chain management. Accordingly, the positive link between green innovation and firm performance implies that technological innovation progressions that consider the environmental impacts can result in increased performance among firms (Handayani et al.,

* Corresponding author

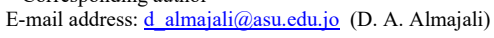

(C) 2021 Growing Science Ltd. All rights reserved.

doi: $10.5267 /$ j.uscm.2021.7.012 
2017). As a result, the notions of green supply chain management, green innovation, and firm performance are becoming increasingly important for Jordanian companies. Furthermore, the prevalence of trust implies a healthy business environment because it demonstrates the depth of ties between different commercial groups. Among the information and communication technology (ICT) managers, there has been a conviction that ICT implementation is influenced by a variety of factors, such as managers' decisions to implement new ICT, resistance management, executive skills, ability, and flexibility of management, and so on (Gurstein, 2007). According to previous research, older managers, particularly those who completed their education in the 1970s, were inclined to form their decisions based on their personal experiences rather than using the information systems (Davis, 1989). In fact, most of these senior executives saw no value of ICT implementation within the workplace. Furthermore, these managers were afraid towards power and/or position loss. As a potential solution, firms have been implementing awareness and training programs. Contrariwise, some managers felt that they were under threat and that they should boost their practices and behavior as well as develop themselves to deal with the rapid pace of change in their organizations (Tarhini et al., 2015).

This study was carried out to discover how Jordanian businesses might boost their performance by embracing the concepts of green innovation, green supply chain management, and trust. Positive organizational performance can aid in increasing production to maximum capacity, having appropriate human resources, expanding market share, and increasing profitability (Almajali et al., 2015). This research contributes to the minimal facts and information relating to green supply chain management, green innovation, trust, and firm performance that has been found in earlier studies. However, there are still gaps within the green supply chain management investigation because the objectives of firm performance are focused differently (Liu et al., 2018). The goal of the present study was to see how green supply chain management and green innovation impact firm performance, as well as how green supply chain management influences green innovation. Additionally, the study attempted to determine if green innovation mediates the impact of green supply chain management on firm performance. Equally, the study attempted to ascertain the influence of trust on the company's success.

\section{Literature Review}

\subsection{Green Supply Chain Management}

In practice, green supply chain management, which includes technological measures, the setting up of new equipment, supplier training, and employee allocation, aims to earn significant income while paying attention to environmental competence (Sugandini et al., 2020). Executives must use the green supply chain management idea so that they could boost the company's productivity while also complying with regulatory requirements addressing environmental impacts (Khaksar et al., 2016). The purpose of GSCM, as stated in Geng et al. (2017), is to improve the profitable, environmental, equipment, and common performance of an organization. Green supply chain management can address a variety of issues, such as stakeholder adoption of green practices, a lack of incentive among stakeholders concerning the application of green supply chain management, and so on (Wibowo et al., 2018).

\subsection{Green Innovation}

Green innovation is a technological improvement that enables businesses to create environmentally friendly goods, conserve energy, reduce toxic waste, reprocess trash, and enhance environmental management practices in order to maintain long-term sustainability. Green innovation is a critical company factor in terms of production and resource management that considers environmental impacts, and this fact demonstrates green innovation's importance in light of the growing global environmental concern (Khaksar et al., 2016). Businesses can boost productivity, maximize internal operations, and save operational costs by introducing environmentally friendly innovations (Aguilera \& Ortiz, 2013). Firm managers should acknowledge green innovation as a critical factor in implementing a competitive advantage, in meeting the expectations of stakeholders and the requirements of the market, as well in achieving sustainable growth for increasing firm performance (Soewarno et al., 2019).

\subsection{Trust}

Initial trust is defined as a need of a given individual to meet his or her requirements with no prior experience or accurate and relevant information (Kim \& Prabhakar, 2004; Gao \& Waechter, 2017). For users with little or no prior experience with new technology, establishing trust is crucial (Shahbaz et al., 2019).

\subsection{Firm Performance}

Firm performance entails a multifaceted notion with three measures, such as manufacturing, economics, and promotion, which can boost a company's profit growth rate. Companies face numerous risks in establishing, maintaining, and improving firm performance because of ambiguity and an increasingly competitive market (Halim et al., 2017). The degree to which a company's manufacturing, store, promotion, and economic objectives are met is referred to as firm performance (Abeysekara et al., 2019; Almajali et al., 2021c). 


\subsection{Green Supply Chain Management and Green Innovation}

Within the supply chain of a given firm, negotiations between stakeholders that may initiate green innovation to meet demand of external sources (e.g., government and regulators) become the link between green supply chain management and green innovation. Abu Seman et al. (2019) and Yang (2019) accordingly highlighted the mutual advantage of green supply chain management and green innovation, noting the significant and positive impact of green supply chain management having on green innovation. Companies should closely examine and control their suppliers to ensure that environmentally friendly resources are provided and that customer expectations are met with such resources to have a successful green innovation implementation. As a result, the researchers came up with the hypothesis below:

\section{H1: Green supply chain management has a positive effect on green innovation.}

\subsection{Green Innovation and Firm Performance}

Green innovation, a technology for generating environmentally friendly products, has been shown to enhance marketing and sales, resulting in reliable company performance. Obtaining market share recognition is a measure of the firm's performance as well as a sign of the success of green innovation. Firms applying green innovation increase company performance, according to Ma et al. (2018). As a result, the researcher came up with the next hypothesis:

\section{$\mathbf{H}_{2}$ : Green innovation has a positive effect on firm performance.}

\subsection{Green Supply Chain Management and Firm Performance}

Green supply chain management, which is being used to protect the environment, can assist firms in lowering raw goods prices and increasing the use of recycled materials, resulting in increased profitability and improved firm performance. Green supply chain management, according to Choi and Hwang (2015), can benefit firm performance by assisting companies in developing modified environmental management, which leads to improved firm performance. Indeed, it imparts a positive impact on company performance, showing that it may help businesses gain a competitive advantage and enhance financial performance over time (Khan \& Qianli, 2017). As a result of this disagreement, the hypothesis below is brought forth:

\section{H3: Green supply chain management has a positive effect on firm performance.}

\subsection{The Mediating Effect of Green Innovation}

Green innovation, according to Hazarika and Zhang (2019), can demonstrate a company's ability to compete for market share, grow the economy, develop items for consumption networks, while also enhancing the socio-technical environment. Companies can considerably preserve and improve firm performance by using green innovation to reduce environmental effects disputed by external parties (Abu Seman et al., 2019). As a result, the researcher came up with the next hypothesis:

\section{$\mathrm{H}_{4}$ : Green innovation mediates the impact of green supply chain management on firm performance.}

\subsection{Trust and Firm Performance}

The trust is based on the likelihood of positive results from other parties' potential events (Zhou, 2013) as well as their vulnerability. Aptitude, integrity, and generosity are three convictions that are commonly associated with trust (Zhou, 2013). Users of a variety of services, such as Online Health Consultation Services (Gong, Han, Li, Yu, \& Reinhardt, 2019) and public e-services, have been proven to value confidentiality (Alabdallat, 2020). A rising corpus of research shows that trust is an essential factor in determining organizational productivity (Almajali et al., 2015c). As a result, we came up with the following hypothesis:

H5: Trust has a positive impact on firm performance.

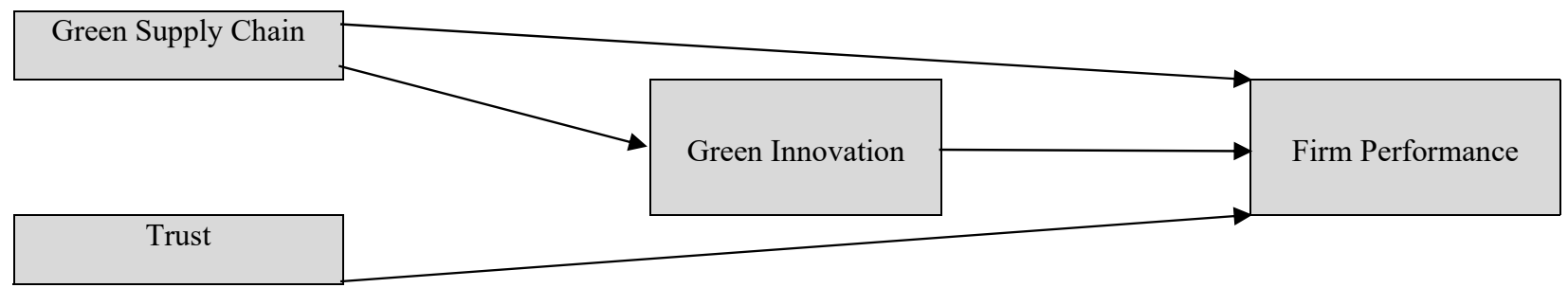

Fig. 1. The proposed research model 


\section{Research Methodology}

\subsection{Pilot Test and Data Collection}

A pilot test was conducted with two MIS academic experts. They were chosen by the researchers based on their prior experience with supply chain management. The sample frame was determined by Jordan Industrial Estates Company (https://www.jiec.com). Purposive sampling may be the optimal method of sampling (Sekaran, 2003). Table 1 shows the respondents' demographics, which include their age and educational level. The total number of companies in the three regions is 390 . A total of 196 questionnaires were issued, and 120 managers responded to the survey, resulting in a $61 \%$ response rate.

Table1

Respondents' characteristics (N: 120)

\begin{tabular}{lll}
\hline Characteristics & Number & Percentage \\
\hline Age & & \\
$30-39$ & 30 & $25 \%$ \\
$40-49$ & 20 & $16 \%$ \\
$50-59$ & 70 & $58 \%$ \\
Educational level & & \\
Diploma & 5 & $4 \%$ \\
Bachelor's degree & 80 & $66 \%$ \\
Master degree & 10 & $8 \%$ \\
Others & 25 & $20 \%$ \\
\hline
\end{tabular}

\subsection{Construct Measurement}

To meet the objective of the study, a survey was utilized to gather data and to find a sample of relevant managers. The use of green supply chain management was evaluated involving the use of 5 items adapted by Sharma et al. (2017), Tseng and Chiu (2013), and Wibowo (2018). For trust, a 5-item scale has been established (Gibson, 2002). Agustia et al. (2019) created a 4item scale to assess Green Innovation. Furthermore, to evaluate firm performance, 6 items were adapted by different sources (Khan \& Watts, 2009; Coltman et al., 2011; Fagbemi \& Olowokudejo, 2013). The measurement items were modified to fit the research domain, and a 5-point Likert scale ranging from 1 that denotes strongly disagree, to 5 that denotes strongly agree, was used as an item scoring tool.

\subsection{Data Analysis and Result}

\subsubsection{Structure Reliability Assessment}

It is necessary to assess each measure of the reliability of the correlation using Alpha Cronbach. Some researchers (such as Hair et al., 1998) recommend values of alpha-Cronbach between 0.60 and 0.70 . As can be observed in Table 2, the depiction of the scale elements and the reliability of the observed elements in the survey structures all fall within the range of 0.70 0.83. Meanwhile, the research structures all exceeded the proposed Cronbach's Alpha value, that is, they are all between 0.60 and 0.70 . Hence, the degree was revealed. Satisfactory and compound reliability values ranged from 0.74 to 0.86 as shown in Table 3. As can be observed, all the values were larger than the suggested value of more than 0.60 (Bagozzi \& Yi, 1988).

\subsubsection{Assessing the Constructs' Validity}

Convergent validity tests are required in the measuring paradigm. This is to provide verification that the indicators on a scale collectively load on a single construct. On the other hand, discriminant validity testing assures that the established items for measuring various constructs really evaluate those constructs.

Table 2

The scales reliabilities $(\mathrm{N}=120)$

\begin{tabular}{lll}
\hline Constructs & Indicators & Cronbach's alpha \\
\hline Green supply chain management & GSC1-GSC5 & 0.72 \\
Trust & TR1-TR5 & 0.83 \\
Green Innovation & GI1-GI4 & 0.70 \\
Firm performance & FP1-FP6 & 0.81 \\
\hline
\end{tabular}

\subsubsection{Convergent Validity}

As indicated in Table 3, the researcher looked at the standard regression weights of the research indicators. It was discovered that several of them demonstrated a low burden on the underlying variables (less than 0.50 , as advised by Newkirk and Lederer (2006), $(\mathrm{GSC} 5=0.402, \mathrm{TR} 1=0.322$, GI1 $=0.274, \mathrm{FP} 5=0.331, \mathrm{FP} 6=0.266)$ in particular. Furthermore, all of these items 
were eliminated and excluded from further analysis since they did not match the recommended minimum value for factor 0.50 downloads (Newkirk \& Lederer, 2006).

\subsubsection{Discriminant Validity}

The validity of the discrimination in the measurement model, according to Fronell and Larker (1981), can be tested by looking at the extracted mean co-contrast (AVE) using latent combinations. In addition, the connections between search structures can be utilized to assess the validity of the differentiation by looking for any extremely high correlations. The presence of such strong correlations indicates that there is a discriminant validity problem.

Table 3

Factor loadings and reliability

\begin{tabular}{|c|c|c|}
\hline Construct & Factor loading & Composite reliability \\
\hline Green supply chain management & & 0.82 \\
\hline GSC1 & 0.512 & \\
\hline GSC2 & 0.532 & \\
\hline GSC3 & 0.544 & \\
\hline GSC4 & 0.578 & \\
\hline Trust & & 0.74 \\
\hline TR2 & 0.533 & \\
\hline TR3 & 0.542 & \\
\hline TR4 & 0.582 & \\
\hline TR5 & 0.574 & \\
\hline Green Innovation & & 0.75 \\
\hline GI2 & 0.592 & \\
\hline GI3 & 0.555 & \\
\hline GI4 & 0.522 & \\
\hline Firm performance & & 0.86 \\
\hline FP1 & 0.519 & \\
\hline FP2 & 0.598 & \\
\hline FP3 & 0.547 & \\
\hline FP4 & 0.537 & \\
\hline
\end{tabular}

Furthermore, discriminatory validity occurs when the AVE for all constructs surpasses the square connection between the given construct and any other structures (Fronell \& Larcker, 1981). Table 4 demonstrates that using Fronell and Larker's (1981) formula to calculate the mean variance collected from a latent structure, this research found that all combinations elucidated $50 \%$ or more of the variance, with values ranging from 0.60 to 0.78 , satisfying the commendation that AVE values should be 0.50 at minimum. Table 4 also shows that the differentiation was supported since AVE values for each group of structures were more than square associations. As a result, the metrics differed dramatically. Therefore, measures significantly differentiated structures.

\subsubsection{Assessment of Measurement Model}

The $\mathrm{x}^{2} / \mathrm{df}$ ratio is another indicator that requires three or fewer values for a model to be acceptable (Kline, 2011). The better fit in the scenario, the lower the percentage value. However, some studies (for example, James et al., 1982) advocated a ratio of 2 to 5. Also, the AGFI, NFI, IFI, TLI, and CFI values that fall within the range of 0.80-0.90 would be deemed tolerable ( Bentler and Bonett, 1980). Notably, the RMSEA value computation considers the model's goodness-of-fit. The acceptable values should be in the range of 0.05 to 0.08 (Hair et al., 1998). As a result, the findings provide affirmation of the match between the study's measurement model and the obtained data (see Table 5).

Table 4

AVE and square of correlations between constructs

\begin{tabular}{lllll}
\hline & GSC & TR & GI & FP \\
\hline GSC & 0.74 & & & \\
TR & 0.144 & 0.70 & & \\
GI & 0.104 & 0.134 & 0.60 & 0.78 \\
FP & 0.122 & 0.120 & 0.163 & \\
\hline
\end{tabular}

\section{Table 5}

Fit indices for measurement and structural model

\begin{tabular}{lccc}
\hline Quality of fit measure & Recommended value & Measurement model & Structural model \\
\hline x2/df & $2-5$ & 1.75 & 0.71 \\
AGFI & $0.80-0.90$ & 0.81 & 0.82 \\
CFI & $0.80-0.90$ & 0.70 & 0.86 \\
TLI & $0.80-0.90$ & 0.78 & 0.88 \\
IFI & $0.80-0.90$ & 0.72 & 0.84 \\
NFI & $0.80-0.90$ & 0.042 & 0.89 \\
RMSEA & $0.05-0.08$ & & 0.074 \\
\hline
\end{tabular}




\section{Hypotheses Testing and Result of the Study}

This empirical investigation presents intriguing results for discussion, extending past extant researches, particularly those relating to green supply chain management and company performance. Five propositions linked to the study's goals were generated and tested, as shown in Table 6. Five concepts were found to be viable. Each C.R. parameter is listed in Table 6 estimate. As shown, green supply chain management imparts substantial positive and direct impact on green innovation $(\mathrm{P}=$ 0.012). As a result, $\mathrm{H} 1$ is supported. Green innovation has a significant positive impact on firm performance $(\mathrm{P}=* *)$. Hence, $\mathrm{H} 2$ is likewise supported. Green supply chain management imparts no influence on company performance for $\mathrm{H} 3(\mathrm{P}=0.114)$, which means that the conjecture is not supported. Green Innovation imparts a strong positive influence on trust $(\mathrm{P}=0.011)$, lending support to $\mathrm{H} 4$.

\section{Table 6}

Summary of the proposed results

\begin{tabular}{|c|c|c|c|c|c|}
\hline \multicolumn{2}{|c|}{ Research proposed paths } & \multirow{2}{*}{$\frac{t \text {-value (CR) }}{3.12}$} & \multirow{2}{*}{$\begin{array}{l}\text { Coefficient value (std. estim) } \\
1.12\end{array}$} & \multirow{2}{*}{$\begin{array}{l}\text { P-value } \\
0.012\end{array}$} & \multirow{2}{*}{$\begin{array}{l}\text { Results } \\
\text { Supported }\end{array}$} \\
\hline GSC & $\rightarrow \quad$ GI & & & & \\
\hline GI $\rightarrow$ & FP & 2.244 & 4.203 & $* *$ & Supported \\
\hline GSC & $\rightarrow \quad \mathrm{FP}$ & 2.446 & 2.522 & 0.114 & Not Supported \\
\hline $\mathrm{TR} \rightarrow$ & FP & 3.117 & 4.188 & 0.011 & Supported \\
\hline
\end{tabular}

\subsection{Result of Green Innovation as a Mediating Effect}

As stated in Table 7, for this study, the researchers investigated the effects of Green Innovation on the link between green supply chain management and company performance. Another important finding of the empirical findings was that Green Innovation appeared to mediate the link between Green supply chain management and business performance (direct effect 0.041 less than indirect effect 0.075 ). As a result, H5 was supported.

Table 7

Summary of the proposed result for mediating effect.

\begin{tabular}{llllllll}
\hline Hypothesis & From & Mediation & To & Direct effect & Indirect effect & Total & Result \\
\hline H5 & GSC & GI & FP & 0.041 & 0.075 & 0.116 & Mediating \\
\hline
\end{tabular}

\subsection{Discussion}

The direct and indirect relationships were investigated in this study. The direct relationship examined the impact of green supply chain management and green innovation on business performance. Green innovation was investigated as a mediating factor for the association between green supply chain management and firm performance in the indirect relationship. Furthermore, there is a direct connection between firm performance and trust. The first hypothesis in this study was that organizations that apply green supply chain management by selecting environmentally conscious suppliers would have the capacity in promoting green innovation. In agreement to this finding, Abu Seman et al. (2019) found the integration of green supply chain management in a company as critical for increasing its green innovation. Purchasing unrefined resources from environmentally sociable suppliers, for example, would considerably aid the development of green innovation. The second hypothesis demonstrated that green innovation and firm performance were linked. Such discovery was consistent with Zhang et al. (2019) who reported that implementing green innovation might enhance firm performance by increasing sales expansion and net profits. Companies might withstand competitive pressure and improve sales by implementing green innovation, which would have a positive effect on firm performance.

The third hypothesis showed no link between green supply chain management and firm performance. According to Kirchoff and Mollenkopf (2016), firms need a lot of incentives to apply green supply chain management to increase their reputation, competence, usefulness, distinctiveness, and income expansion. Furthermore, the present study found that the use of green innovation as mediator resulted in a direct relationship between green supply chain management and firm performance. Green innovation may be able to moderate the link between green supply chain management and company success in this regard. A study by Chiou et al. (2011) reported a similar finding. This hypothesis assumes that improving green supply chain management would enhance green innovation while also improving firm performance. The environmental concerns have caused companies to focus more on green supply chain management, and thus, these companies act in a more environmentally friendly manner when obtaining raw materials from suppliers, while also utilizing green innovation to enhance firm performance. Also, this study demonstrates a link between trust and corporate performance. Almajali et al. (2015) validated this conclusion by focusing on the linkage between user trust and firm productivity. Equally, the present study is of value in assisting companies to understand how to increase environmental protection by applying green supply chain management and green innovation, to boost their success. Further, green supply chain management is applied by companies to manage environmental issues. In this context, green supply chain management refers to the way firms receive resources from suppliers, convert the aforesaid resources into completed goods which are then delivered to customers, taking the environmental issues into account. Furthermore, the introduction of green innovation into the manufacturing processes of firms paid close 
concentration to environmental implications. Green innovation in companies should be able to provide a thorough examination of green supply chain management to boost their performance.

\subsection{Limitation and Further Research}

This study does have some limitations. First, companies registered on www.jiec.com in Jordan were used in this study. Because Jordan Industrial Estates is a corporation with a good environmental track record, this study of green supply chain management and green innovation may be skewed. It may be subjective as well. Other sorts of companies with environmental consequences, such as health care companies, are expected to become study samples in the next related studies. Second, the focus of this study was solely on green supply chain management and firm performance. Other characteristics, such as green innovation intensity, could be used in future studies to analyze firm performance (Aguilera \& Ortiz, 2013).

\section{Reference}

Almajali, D., Masa'deh, R., \& Tarhini, A. (2016a). Antecedents of ERP systems implementation success: a study on Jordanian healthcare sector. Journal of Enterprise Information Management, 29(4), 549-565.

Almajali, D., Hammouri, Q., \& Barakat, S. (2021b). E-learning through COVID-19 crisis in Developing Countries. International Journal of Pharmaceutical Research, 13(1), 5543-5553.

Almajali, D. A., Maqableh, M., Masa'deh, R. (2015). Assessing the digital divide status of the Jordanian telecentre. International Journal of Communications, Network and System Sciences, 8(11), 428-439.

Abu Seman, N. A. A., Govindan, K., Mardani, A., Zakuan, N., Saman, M. Z. M., Hooker, R. E., \& Ozkul, S. (2019). The mediating effect of green innovation on the relationship between green supply chain management and environmental performance. Journal of Cleaner Production, 229, 115-127.https://doi.org/10.1016/j.jclepro.2019.03.211.

Agustia, D., Sawarjuwono, T., \& Dianawati, W. (2019). The mediating effect of environmental management accounting on green innovation - Firm value relationship. International Journal of Energy Economics and Policy, 9(2), $299-306$. https://doi.org/10.32479/ijeep.7438.

Aguilera-Caracuel, J., \& Ortiz-de-Mandojana, N. (2013). Green Innovation and Financial Performance: An Institutional Approach. Organization and Environment, 26(4), 365-385. https://doi.org/10.1177/1086026613507931.

Alabdallat, W. I. M. (2020). Toward a mandatory public e-services in Jordan. Cogent Business \& Management, 7(1), 1727620.

Abeysekara, N., Wang, H., \& Kuruppuarachchi, D. (2019). Effect of supply-chain resilience on firm performance and competitive advantage: A study of the Sri Lankan apparel industry. Business Process Management Journal, 25(7), 16731695. https://doi.org/10.1108/BPMJ-09-2018-0241.

Bagozzi, R., \& Yi, Y. (1988) On the Evaluation of Structural Equation Models. Journal of the Academy of Marketing Sciences, 16, 74-94. http://dx.doi.org/10.1007/BF02723327

Bentler, P.M., \& Bonett, D.G. (1980) Significance Tests and Goodness of Fit in the Analysis of Covariance Structures. Psychological Bulletin, 88, 588-606. http://dx.doi.org/10.1037/0033-2909.88.3.

Choi, D., \& Hwang, T. (2015). The Impact of Green Supply Chain Management Practices on Firm Performance: The Role of Collaborative Capability. Operations Management Research, 8(3-4), 69-83. https://doi.org/10.1007/s12063- 015-0100-x.

Coltman, T., Devinney, T., \& Midgley, D. F. (2011). Customer relationship management and firm performance. Journal of Information Technology, 26, $205-219$.

Davis, F.D. (1989) Perceived Ease of Use, and User Acceptance of Information Technology. MIS Quarterly, 13, $319-340$. http://dx.doi.org/10.2307/249008

Fagbemi, A., \& Olowokudejo, F. (2013). Customer relationship management as a correlate of organizational performance in Nigerian banks. Elixir Marketing Management, 56, 13547 - 13555.

Fornell, C., \& Larcker, D. F. (1981). Evaluating Structural Equation Models with Unobservable Variables and Measurement Error. Journal of Marketing Research, 18(1), 39-50.

Gong, Z., Han, Z., Li, X., Yu, C., \& Reinhardt, J. D. (2019). Factors Influencing the Adoption of Online Health Consultation Services: The Role of Subjective Norm, Trust, Perceived Benefit, and Offline Habit. Front. Public Health, $7,286$. https://doi.org/10.3389/fpubh.2019.00286.

Ge, B., Yang, Y., Jiang, D., Gao, Y., Du, X., \& Zhou, T. (2018). An Empirical Study on Green Innovation Strategy and Sustainable Competitive Advantages: Path and Boundary. Sustainability, 10(10), 1-18. https://doi.org/10.3390/su10103631.

Geng, R., Mansouri, S. A., \& Aktas, E. (2017). The Relationship between Green Supply Chain Management and Performance: A Meta-Analysis of Empirical Evidences in Asian Emerging Economies. International Journal of Production Economics, 183(October 2016), 245-258. https://doi.org/10.1016/j.ijpe.2016.10.008.

Gibson, B. J., Rutner, S.M., \& Keller, S. B. (2002). Shipper Carrier Partnership Issues, Rankings and Satisfaction. International Journal of Physical Distribution and Logistics Management, 32, 669-681. http://dx.doi.org/10.1108/09600030210444917.

Gurstein, M. (2007). What Is Community Informatics: (And Why Does It Matter)? Polimetrica, Milano

Gao,L., \& Waechter, K.(2017). Examining the role of initial trust in user adoption of mobile payment services: an empirical investigation. Information system Frontiers, 19(3),525-548. 
Halim, E. H., Mustika, G., Sari, R. N., Anugerah, R., \& Mohd-Sanusi, Z. (2017). Corporate governance practices and financial performance: The mediating effect of risk management committee at manufacturing firms. Journal of International Studies, 10(4), 272-289. https://doi.org/10.14254/2071-8330.2017/10-4/21.

Handayani, R., Wahyudi, S., \& Suharnomo, S. (2017). The effects of corporate social responsibility on manufacturing industry performance: The mediating role of social collaboration and green innovation. Business: Theory and Practice, 18, 152159. https://doi.org/10.3846/btp.2017.016.

Hazarika, N., \& Zhang, X. (2019). Evolving theories of eco-innovation: A systematic review. Sustainable Production and Consumption, 19, 64-78.

Hair, J., Black, W., Babin, B., Anderson, R., \& Tatham, R. (1998). Multivariate Data Analysis. Prentice Hall, Upper Saddle River, NJ.

James, L., Mulaik, S., \& Brett, J. (1982). Causal Analysis: Assumptions, Models, and Data. Sage Publications, Beverly Hills.

Khan, S. A. R., \& Qianli, D. (2017). Impact Of Green Supply Chain Management Practices on Firms' Performance: An Empirical Study From The Perspective of Pakistan. Environmental Science and Pollution Research, 24(20), 16829-16844.

Khan, M., \& Watts, R. (2009). Estimation and empirical properties of a firm-year measure of accounting conservatism. Journal of Accounting and Economics, 48(2-3), 132 - 150.

Khaksar, E., Abbasnejad, T., Esmaeili, A., \& Tamošaitienė, J. (2016). The Effect of Green Supply Chain Management Practices on Environmental Performance and Competitive Advantage: A Case Study of The Cement Industry. Technological and Economic Development of Economy, 22(2), 293-308. https://doi.org/10.3846/20294913.2015.1065521.

Kaabachi, S., Mrad, S. B., \& O'Leary, B. (2019). Consumer's initial trust formation in IOB's acceptance: The role of social influence and perceived compatibility. International Journal of Bank Marketing, 37, 507-530. https://doi.org/10.1108/IJBM-12-2017- 0270.

Kim, K. K., \& Prabhakar, B. (2004). Initial trust and the adoption of B2C e-commerce: The case of internet banking. $A C M$ SIGMIS Database: the DATABASE for Advances in Information Systems, 35(2), 50-64.

Kline, R.B. (2011). Principles and Practice of Structural Equation Modeling. $2^{\text {nd }}$ ed., The Guilford Press, New York.

Liu, J., Feng, Y., Zhu, Q., \& Sarkis, J. (2018). Green supply chain management and the circular economy: Reviewing theory for advancement of both fields. International Journal of Physical Distribution and Logistics Management, 48(8), 794817. https://doi.org/10.1108/IJPDLM-01-2017-0049.

Ma, Y., Yin, Q., Pan, Y., Cui, W., Xin, B., \& Rao, Z. (2018). Green Product Innovation And Firm Performance: Assessing The Moderating Effect Of Novelty-Centered And Efficiency-Centered Business Model Design. Sustainability (Switzerland), 10(6), 1-13. https://doi.org/10.3390/su10061843.

Naqvi, M. H. A., Jiang, Y., Miao, M., \& Naqvi, M. H. (2020). The effect of social influence, trust, and entertainment value on social media use: Evidence from Pakistan. Cogent Business \& Management, $7(1)$. https://doi.org/10.1080/23311975.2020.1723825.

Newkirk, H. E., \& Lederer, A. L. (2006). The effectiveness of strategic information systems planning under environmental uncertainty. Information \& Management, 43(4), 481-501.

Shahbaz, M., Gao, C., Zhai, L., Shahzad, F., \& Hu, Y. (2019). Investigating the adoption of big data analytics in healthcare: the moderating role of resistance to change. Journal of Big Data, 6(1), 1-20. https://doi.org/10.1186/s40537-019-0170-y.

Sekaran, U. (2003). Research Methods for Business. John Wiley \& Sons.

Soewarno, N., Tjahjadi, B., \& Fithrianti, F. (2019). Green innovation strategy and green innovation: The roles of green organizational identity and environmental organizational legitimacy. Management Decision, 57(11), 3061-3078.

Sugandini, D., Muafi, M., Susilowati, C., Siswanti, Y., \& Syafri, W. (2020). Green Supply Chain Management and Green Marketing Strategy on Green Purchase Intention: SMEs Cases. Journal of Industrial Engineering and Management, 13(1), 79-92. https://doi.org/10.3926/jiem.2795.

Sharma, V. K., Chandna, P., \& Bhardwaj, A. (2017). Green supply chain management related performance indicators in agro industry: A review. Journal of Cleaner Production, 141, 1194-1208. https://doi.org/10.1016/j.jclepro.2016.09.103.

Tarhini, A., Ammar, H., Tarhini, T., \& Masa'deh, R. (2015) Analysis of the Critical Success Factors for Enterprise Resource Planning Implementation from Stakeholders' Perspective: A Systematic Review. International Business Research, 8, $25-$ 40. http://dx.doi.org/10.5539/ibr.v8n4p25

Tseng, M. L., \& Chiu, A. S. F. (2013). Evaluating firm's green supply chain management in linguistic preferences. Journal of Cleaner Production, 40, 22-31. https://doi.org/10.1016/j.jclepro.2010.08.007.

Wibowo, M. A., Handayani, N. U., \& Mustikasari, A. (2018). Factors For Implementing Green Supply Chain Management In The Construction Industry. Journal of Industrial Engineering and Management, 11(4), 651-679.

Yang, Z., Sun, J., Zhang, Y., \& Wang, Y. (2019). Perceived fit between green IS and green SCM: Does it matter? Information and Management, 56(7), 103154. https://doi.org/10.1016/j.im.2019.02.009.

Zhou, T. (2013), An empirical examination of continuance intention of mobile payment services. Decision Support Systems, 54(2), 1085-1091.

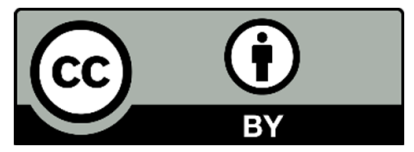

(C) 2021 by the authors; licensee Growing Science, Canada. This is an open access article distributed under the terms and conditions of the Creative Commons Attribution (CCBY) license (http://creativecommons.org/licenses/by/4.0/). 